УДК: 338.001 .36

\title{
A comparative analysis of national innovation systems' structures and their developmental impacts (Evidences from BRICS countries)
}

\author{
Alnafrah Ibrahim ibrahimalnafrah@gmail.com \\ ITMO University \\ 49, Kronverksky pr. St. Petersburg, 197101, Russia \\ Ph.D. Al Naimi Kasem dr.kasemn@gmail.com \\ Damascus University \\ Ahmad Marah marah2ahmad@gmail.com \\ ITMO University \\ 49, Kronverksky pr. St. Petersburg, 197101, Russia
}

The BRICS countries are undergoing a decisive economic and social transition towards a knowledge-based economy. In this new economy, innovation activities are the cornerstone of economic dynamics and mechanisms of value creation. Therefore, the construction and development process of NISsis an essential element in the process of transformation towards a knowledge-based economy and strengthening the competitive position of BRICS countries globally. This study aims to analyze the factors' structure of NISs in the BRICS countries, taking into account that these countries are undergoing a rapid and radical change in terms of national economic models. It also aims to analyze NIS impacts on the key economic and social development indicators. In order to achieve these objectives, we analyzed a set of indicators of NISs that reflect the main dimensions of these systems: innovation, institutional, infrastructural and educational dimensions. In addition to an economic and social development dimension in these countries during the period 20002015. Regarding the methodology, the panel data analysis was used to analyze the relationship between the dimensions of NISs and the economic performance in the BRICS countries combined. The results showed that there are structural differences among the BRICS countries in terms of NISs dimensions. Where the Russian innovation system is the best national innovation system among the BRICS countries, while the innovation system in India has the lowest performance. The analysis of the overall relationship between the dimensions of NISs and economic performance showed a significant positive relationship. While the partial analysis in each country showed clear structural differences among studied countries. Where there was generally a weakness in the innovation and institutional dimension in these countries.

Keywords: national innovation system, knowledge-based economy, emerging economies, BRICS countries, economic and social development.

DOI: $10.17586 / 2310-1172-2018-11-1-13-20$

\section{Сравнительный анализ структур национальных инновационных систем и их влияние на экономическое развитие (Свидетельства из стран БРИКС)}

\author{
Альнафра Ибрагим ibrahimalnafrah@gmail.com \\ Университет ИТМО \\ 197101, Россия, Санкт-Петербург, Кронверкский пр.,49 \\ Канд. экон. наук Найми Касем dr.kasemn@gmail.com \\ Университет Дамаска \\ Дамаск, Альпарамке \\ Ахмад Мара marah2ahmad@gmail.com \\ Университет ИТМО \\ 197101, Россия, Санкт-Петербург, Кронверкский пр.,49
}

Страны БРИКС претерпевают рещающий экономический и социальный переход к экономике, основанной на знаниях. В этой новой экономике инновационная деятельность является основным компонентом 
экономической динамики и механизмов создания стоимости. Поэтому процесс построения и развития национальной инновационной системы является важным элементом процесса перехода к экономике знаний, и усиления конкурентной позиции стран БРИКС во всем мире. Это исследование направлено на анализ структуры факторов НИС в странах БРИКС с учетом того, что эти страны подвергаются быстрым и радикальным изменениям с точки зрения национальных экономических моделей. Оно также направлено на анализ влияния НИС на ключевые показатели экономического и социального развития. Для достиэееия этих целей мы проанализировали набор показателей НИС, которые отражают основные аспекты этих систем: инновационные, институциональные, инфраструктурные и образовательные аспекты. В дополнение к измерению экономического и социального развития в этих странах в период 2000-2015 годов. Что касается методологии, (Panel data analysis) использовался для анализа комбинированных взаимосвязи между размерами НИС и экономическим развитием в странах БРИКС. Результаты показали, что между странами БРИКС существуют структурные различия по размеру НИС. Где российская инновационная система является лучшей национальной инновационной системой среди стран БРИКС, в то время как инновационная система в Индии имеет самую низкую производительность. Анализ общей взаимосвязи между размерами НИС и экономическими показателями показал значительную положительную корреляцию. В то время как частичный анализ в каждой стране показал четкие структурные различия между изученными странами. Там, где, результаты показали слабость инновационного и институционального измерения в этих странах.

Ключевые слова: национальная инновационная система, экономика, основанная на знаниях, страны с формирующимся рынком, страны БРИКС, трансформация, экономическое и социальное развитие.

\section{Introduction}

The economic and social changes that the world economy is experiencing as a result of technological developments have led many economies of the world to move towards building their economic activities by using high technology and adopting the process of transition towards a knowledge-based economy. Where the knowledge-based economy is the economy that based on using, producing, disseminating and exchanging of knowledge and its embodiment into products and services. However, producing these products requires a high level of innovation. The re fore, transforming towards a knowledge-based economy needs to build a national innovation system capable of activating the production dynamics of innovation products. Consequently, increasing the added value produced within the national economy, and improving the economic, social and human development situation in the country.

Regarding the transformation process towards the knowledge-based economy, many emerging economies are experiencing this critical change. Where many of these economies have already begun to adopt policies at the macro and micro levels towards building a knowledge-based economy and society by enhancing their innovation capabilities.

In this article, we will study the BRIC countries as one of the most important emerging economies at the global level, both in terms of the size of their economies, the irproduction structures and their economic relationships among them and with the rest of the world's economies.

The importance of this study lies in providing a structural analysis for NISs' factors in BRICS countries. This analysis is considered an important tool for policy makers to reveal the reality of innovation activities in these countries and give a clear view for the future of innovation and development policies and strategies that must be followed in order to complete the transformation process towards the knowledge-based economy and improve the developmental situation of the population in these countries.

The aim of this study is to identify the structural differences among the NISs' factors in BRICS countries and to determine their developmental impacts in each country. Moreover, this study aims to identify structural strengths and weaknesses associated with NISs in these countries.

\section{Methodology}

Regarding the research methodology, the systematic analytical approach was used to analyze the general framework of NISs structures in the BRICS countries. The inductive approach was also used to analyze the NISs' factors and thus to obtain circulars related to this group of countries. As well as the statistical analysis was carried out for NISs in order to determine the NISs' dimensions impacts on the economic and social development. 


\section{Theoretical background and literature review}

Freeman was the first user of the national innovation system concept in 1982, who defined the national innovation system as «the network of public and private sector institutions engaged in the disseminating, distributing and producing a new technology» [10]. Later, Lundvall presented another definition of the national innovation system from a different point of view, where he defined it as «a set of components and relationships that interact with each other in the production, distribution and exchange of useful new knowledge» [14] .

This concept was subsequently widely studied by many researchers because of the rising importance of building and developing process of national innovation systems in order to catch up with advanced economies based on the intensification of innovation activities within the economy. The concept of NIS has also been studied at more than one level, whether the regional innovation system [13 and 17] or the national innovation system [18] or even the organization-wide innovation system [1 and 19].

Consequently, national innovation system represents asset of actors within the economy and society engaged in the production, distribution and exchanging of new technology, useful knowledge and innovations.

It is clear from the previous definitions that the NIS' activities are closely related to knowledge-based activities, since this type of activities is an essential component in the transition process towards a knowledge-based economy, that represents "a new pattern of modern economy based on the processes of production, exchanging and dissemination of knowledge among economic actors to increase national wealth" [4 and 3].In this context, it is worth to note that the relationship between the knowledge-based economy and the NIS is an interactive and dialectical relationship.

Regarding the empirical studies of innovation systems, there are many comparative studies that analyzed NIS. Where those studies analyzed NIS from general point of view. Such as a Castellacci and Naterastudy [6 and 7] that examined NISs by panel data analysis. In another study, Fagerberg [9] analyzed the NISs for 115 countries, and found that there is a significant relationship between the development level of national innovation systems and the economic growth in the studied countries.

However, these studies did not provide specific structural patterns of the NISs activities in the studied countries. So, this study will investigate the group of BRICS economies, which are considered homogeneous in terms of the nature of economic activities and are converging in terms of technological and development level. In addition to their joint activities within the framework of the BRICS group. This gives particular importance to this study, in providing a structural analysis of the NISs in this group of countries and the prospects for their development.

\section{An overview of the reality of NISs in the BRICS economies}

In order to provide a general framework for analyzing $s$ in the BRICS countries, we will study and analyze a set of indicators divided into four main dimensions: the innovation dimension, the infrastructural dimension, the institutional dimension and the educational dimension.

\section{Innovation dimension}

The innovation dimension is one of the most important dimensions within the NIS. Where the main activities that represent the innovation productivity and intensity of the NIS are the innovation activities associated with - according to Schumpeter's definition - a new product or method of production or the creation of a new organizational style [21].

This dimension can be expressed through a set of indicators that represent the input and output of the innovation process in the studied countries, that linked to the innovation capabilities of these countries.

The analysis of the innovation dimension indicators shows that China is the best BRICS country in terms of the technological activities intensity. Where the volume of expenditure on the use of intellectual property rights represents the intensity of the activities using the outputs of the innovation process. As well as, the number of trademarks in China exceeds all the BRICS countries. It is worth to mention, that all previous indicators were compared in total to population.

In terms of expenditure on $\mathrm{R} \& \mathrm{D}$, which is the main engine of innovation activities and the core of the knowledgebased economy[11], China also outperforms all the BRICS countries by a large margin of 1.99 percent of GDP in 2015.This requires other BRICS countries (Russia, India, Brazil and South Africa) to raise their spending on R \& D activities (public and private) if they want to achieve a competitive edge on the technological production.

At the level of the educational sector, Russia is superior to the BRICS countries by a large margin in terms of the number of students enrolled in higher education. In addition to spending on education as a percentage of GDP. This is indicative of the Russian government's approach to building a strong human capital capable of acquiring the necessary 
technological skills in the future[20].Since the development of human capital is one of the most important factors promoting and supporting innovation [2].

India remains the weakest link among the BRICS countries at the level of innovation. Where R\&D expenditures are among the lowest in the BRICS countries and globally. Thus, greater efforts by India in strengthening R \& D activities are needed to support the patent system as well.

\section{Infrastructural dimension}

Infrastructure in the traditional sense is no longer sufficient to build a knowledge-based economy. Today, a new type of infrastructure is needed to suit the requirements of innovative activities [8]. This is the infrastructure that involves facilitating the production, dissemination and exchange of knowledge and technology among the key actors within the NIS.

The analysis of the infrastructure indicators shows Russia's superiority over the rest of the BRICS countries, both in terms of electricity consumption, or in the number of Internet users and mobile subscribers. This is considered an evidence of the spread of physical infrastructure technology services in Russia - despite the large geographical area to be covered - which facilitate the transfer of information and knowledge among members of the community. While India also suffers from a lack of adequate technological infrastructure, due to the large population, as well as poor regional development planning.

\section{Institutional dimension}

The institutional dimension is an important factor in the NIS for creating an appropriate legal, legislative and institutional environment for innovation activities. Since, the institutional factor is considered to be a supportive, stimulating and attractive for investment in innovation activities. It should be mentioned here that the institutional framework of the NIS has to be directed to attract innovative activities with high technology in the first place [16].

The institutional dimension also includes the degree of economic freedom provided by legislation and laws established by the State in order to facilitate the entrepreneurial activities-based on high technology. As well as the institutional and financial environment in the studied economy and the level of protection of property rights, that is considered an important element encouraging entrepreneurs to intensify their innovation activities as long as the outputs of these activities are protected in a legal framework [12].

The analysis of institutional dimension indicators shows that Russia occupies the last position among the BRICS countries, indicating a weakness at the level of institutional and legislative environment supporting innovation activities. With regard to the credit provided by the financial sector, China ranks first among the BRICS countries, indicating that China's public monetary policies are geared towards facilitating the process of obtaining the necessary funding for creating of new innovation projects. While the proportion of such funding in Russia is very low compared to the rest of the BRICS countries, and therefore there is a need to improve the mechanisms of granting credit for new projects to stimulate innovation activities and increase the number of new entrepreneurial projects.

This dimension includes also the index of financial freedom, which represents the efficiency of banks in the economy in addition to their independence from the government and the degree of competition within the monetary market. At this level, the performance of all the BRICS economies is modest compared to the developed economies - except South Africa and this is due to the intervention of the state in the market and its role as a regulator of the money market. Thus, the BRICS countries need to improve the institutional dimension of their NISs to stimulate high-technology productive activities aimed at generating different types of innovations [15].

\section{Educational dimension}

The education sector is the primary source of economy and society with qualified human capital capable of dealing with new technology. The role of universities in this area is important, considering that universities are the main centers where individuals are able to acquire and produce new knowledge that can be transferred to market innovations [5]. They are also able, through cooperation with the business sector, to increase the accumulation of knowledge - both basic research and applied - and thus accelerate the process of innovation in linear and non-linear form.

The analysis of the educational dimension indicators covering secondary and tertiary education showed that Russia ranks first among all the BRICS countries, where Russia has a high rate of enrollment of students in secondary and higher education. Public expenditure on education is also good compared with the rest of the BRICS, accounting for 3,7\% of total public expenditure in 2015, while India is the weakest country in the BRICS group, and that affects the availability of wellqualified human capital and its capability to produce the necessary knowledge for the innovation process. 


\section{Data, results and discussion}

This study includes analysis data for five BRICS countries during the period 2000-2015. It consists of 20 variables grouped into five main dimensions: four dimensions that represent NISs and one dimension for economic and social performance.

The variables representing the NISs are divided into four main dimensions: the innovation dimension (IF), the infrastructural dimension (INF), the institutional dimension (SF) and the educational dimension (EDF). These four dimensions were grouped according to the principle component analysis (PCA) method in order to reduce the problem of autocorrelation between independent variables in the study. As well as for the economic and social development level variables (ESD), which constitute the dependent variable in this study.

In order to analyze the relationship between the dimensions of the NIS and the economic and social development level in the BRICS countries generally, we used the Panel data analysis. Table (1) shows the results of the relationship between the dimensions of the NIS and the economic and social development level in all BRICS countries.

Table 1

\section{Panel data analysis for nis factors in BRICS countries}

\begin{tabular}{|c|c|c|c|c|}
\hline Variables & \multicolumn{2}{|c|}{ Fixed Effect Model (1) } & Random Effect Model (2) \\
\hline ESD (Dep) & Coefficient & P-value & Coefficient & P-value \\
\hline IF & 0,4720362 & $0,000^{* * *}$ & 0,3195 & $0,000^{* * *}$ \\
\hline INF & 0,1854585 & $0,000^{* * *}$ & $-0,0885$ & 0,275 \\
\hline SF & 0,2874587 & $0,000^{* * *}$ & $-0,1778$ & $0,000^{* * *}$ \\
\hline EDF & 0,1449096 & $0,000^{* * *}$ & 1,0552 & $0,000^{* * *}$ \\
\hline Constant & $6,36 \mathrm{e}-08$ & 1,000 & $-2,94 \mathrm{e}-09$ & 1,000 \\
\hline F-Test & \multicolumn{2}{|c|}{$0,000^{* * *} 0,000^{* * *}$} \\
\hline $\mathrm{R}^{2}$ overall & \multicolumn{2}{|c|}{0,5326} & \multicolumn{2}{c|}{0,9141} \\
\hline Chi $^{2}$ Test & \multicolumn{3}{|c|}{$0,000^{* * *}$} \\
\hline
\end{tabular}

Prepared by researchers $* * *, * *, *$ represent significance at 1,5 , and $10 \%$ level of significance, respectively.

Results show the fixed effect model is the most appropriate to express the relationship between the variables of the study, based on the test $\left(\mathrm{Chi}^{2}\right.$-test) which confirms this result.

Fixed effect model shows that there is a statistically significant relationship between all dimensions of the NISs and the level of economic and social development in all BRICS countries. The degree to which these dimensions affect the level of economic and social development varies. The most influential dimension is the innovation dimension, while the educational dimension has the least impact on the level of economic and social development. However, the results of this meta-analysis do not show the real structural differences between the national innovation systems in the BRICS countries, nor do they correspond to the economic and social reality in these countries. Therefore, in order to investigate in detail, the structural differences of NISs among the BRICS countries and to identify the strengths and weaknesses of each NIS, we analyzed the relationship between the dimensions of the NIS and the level of economic and social development in each country of the BRICS group.

First, we analyzed the structural differences between the systems of innovation in the BRICS countries by running one-wayanova to identify the significant differences between the dimensions of national innovation systems.

The results, as shown in Figs. 1 and 2, show the strengths and weaknesses of the NISs in each of the BRICS countries, and then we arrange these systems in terms of their strengths, giving greater relative weight to both the innovation and educational dimensions. Taking into consideration that the dimension of innovation is the fundamental component and represent the best output of NIS's inputs of human capital. 


\section{Structural Differences among NISs in BRICS Countries}

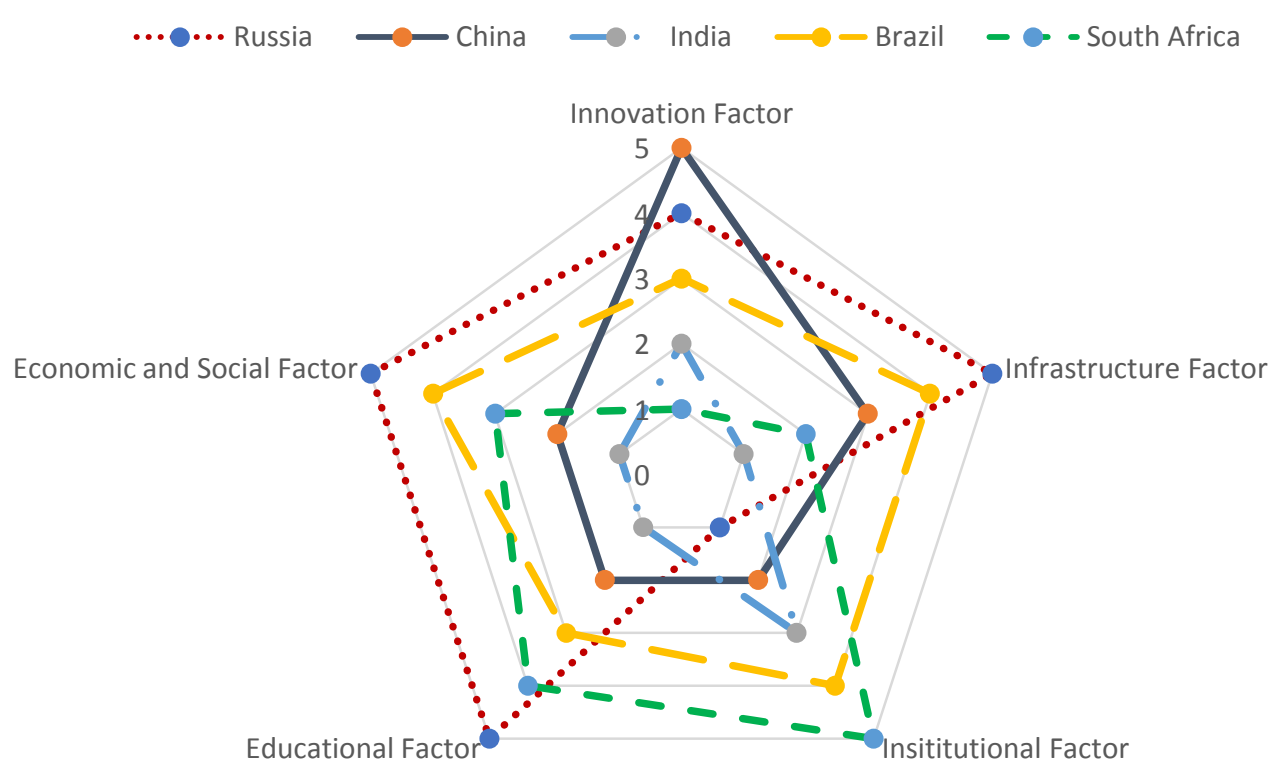

Fig. 1. Structural differences of NISsamong the BRICS countries

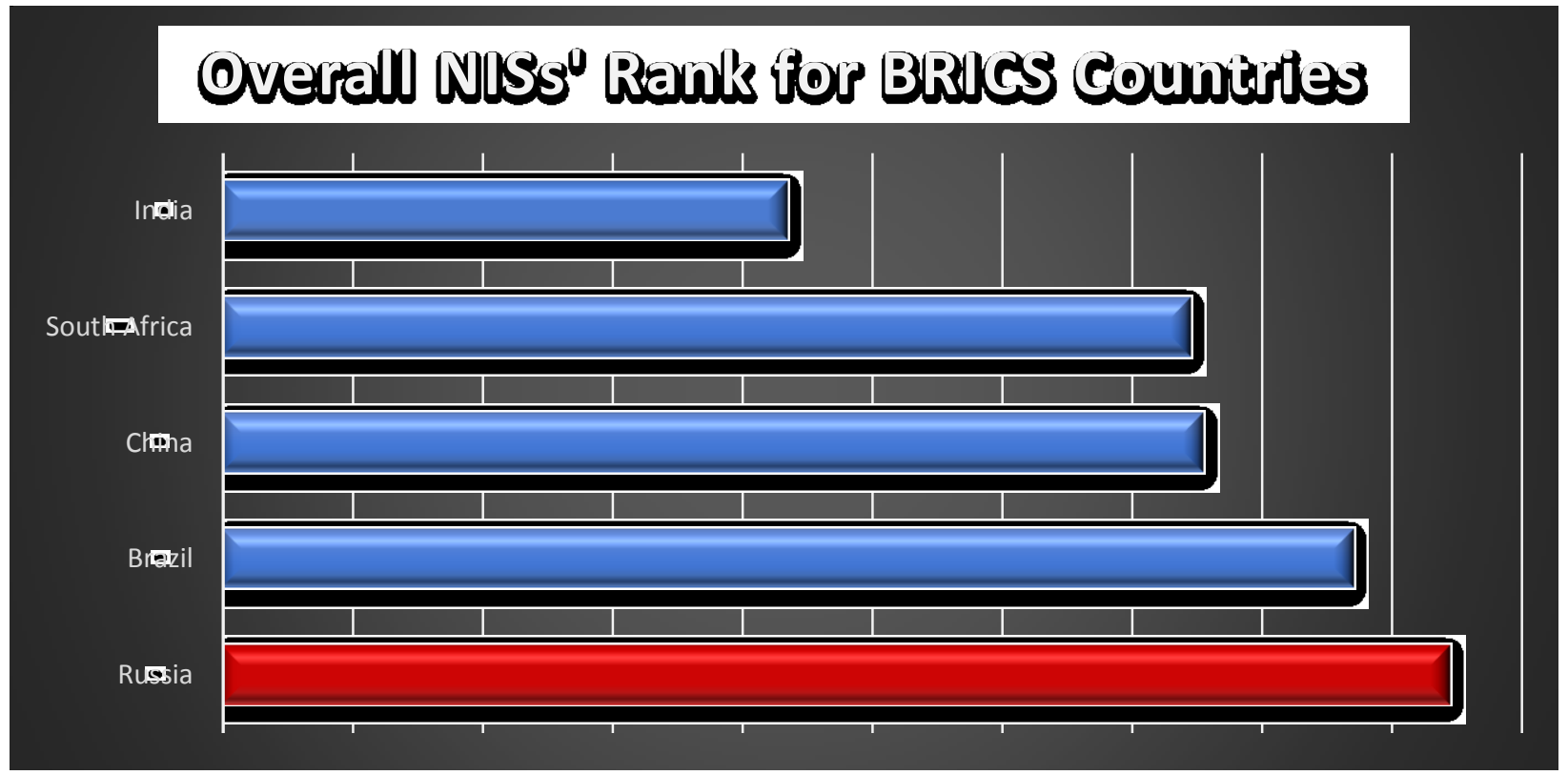

Fig. 2. Overall NISs' Rank of the BRICS countries

For a more in-depth analysis of the structural differences among NISs in the BRICS countries, we have conducted a multiple linear regression for each country in order to determine the impacts of the NISs' dimensions on the level of economic and social development in each country. We obtained the results shown in table (2). 


\section{The results of regression models in the study}

\begin{tabular}{|c|c|c|c|c|c|c|c|c|c|c|}
\hline Variables & \multicolumn{2}{|c|}{ Russia } & \multicolumn{2}{|c|}{ China } & \multicolumn{2}{|c|}{ India } & \multicolumn{2}{|c|}{ Brazil } & \multicolumn{2}{|c|}{ South Africa } \\
\hline $\begin{array}{c}\text { ESD } \\
\text { (Dep) }\end{array}$ & $\begin{array}{c}\text { Coeffi- } \\
\text { cient }\end{array}$ & P-value & $\begin{array}{c}\text { Coeffi- } \\
\text { cient }\end{array}$ & P-value & $\begin{array}{c}\text { Coeffi- } \\
\text { cient }\end{array}$ & P-value & $\begin{array}{c}\text { Coeffi- } \\
\text { cient }\end{array}$ & P-value & $\begin{array}{c}\text { Coeffi- } \\
\text { cient }\end{array}$ & P-value \\
\hline IF & 0,190 & 0,116 & 0,485 & $0,000 * * *$ & 0,109 & 0,539 & $-0,298$ & $0,002 * * *$ & $-0,107$ & 0,298 \\
\hline INF & 0,718 & $0,001 * * *$ & 0,657 & $0,000 * * *$ & 0,132 & 0,488 & 1,157 & $0,000 * * *$ & 0,578 & $0,000 * * *$ \\
\hline $\mathrm{SF}$ & $-0,066$ & 0,457 & 0,099 & $0,089 *$ & 0,276 & 0,142 & 0,157 & $0,069^{*}$ & $-0,046$ & 0,514 \\
\hline EDF & 0,164 & $0,039 * *$ & $-0,042$ & 0,523 & 0,488 & $0,041 * *$ & 0,252 & $0,043 * *$ & 0,505 & $0,001 * * *$ \\
\hline Constant & $4,244 \mathrm{E}-7$ & 1,000 & $1,762 \mathrm{E}-7$ & 1,000 & $5,999 \mathrm{E}-7$ & 1,000 & $4,114 \mathrm{E}-8$ & 1,000 & $-5,599 \mathrm{E}-7$ & 1,000 \\
\hline F-Test & \multicolumn{2}{|c|}{$0,000 * * *$} & \multicolumn{2}{|c|}{$0,000^{* * *}$} & \multicolumn{2}{|c|}{$0,000 * * *$} & \multicolumn{2}{|c|}{$0,000 * * *$} & \multicolumn{2}{|c|}{$0,000 * * *$} \\
\hline Adjusted- $\mathrm{R}^{2}$ & \multicolumn{2}{|c|}{0,989} & \multicolumn{2}{|c|}{0,995} & \multicolumn{2}{|c|}{0,986} & \multicolumn{2}{|c|}{0,988} & \multicolumn{2}{|c|}{0,978} \\
\hline
\end{tabular}

Prepared by researchers. ***, **, * represent significance at 1,5 , and $10 \%$ level of significance, respectively

The previous regression models show that there are clear and significant structural differences between national innovation systems in the BRICS countries. All models are significant at $(\alpha=5 \%)$ and all values of the adjusted coefficient of determination representa good explanatory power for all models as well.

In general, there is a convergence among the NISs in the BRICS countries in terms of the educational and infrastructural dimensions (except India), where there is a significant impact on the economic and social development. Regarding the innovation dimension, this dimension plays a significant role in the development process only in China and Brazil. While the rest of the BRICS countries are weak at the innovation dimension, which is one of the most important dimensions of the NIS.

Regarding the institutional dimension there is a marked weakness in both Russia and India innovation systems. While the role of this dimension in other countries is modest. This shows that there is a general weakness in the BRICS countries at the level of institutional and legislative structure and at the level of innovation activities both at the input and output of the innovation process. Consequently, this will slow down and hinder the process of building and developing NISs in these countries, threatening the success of the transition towards a knowledge-based economy.

\section{Conclusion}

This study showed that there are structural differences among the BRICS countries. Where the impacts of the NISs' dimensions on economic and social development vary structurally among the BRICS countries. This, in turn, illustrates the strengths and weaknesses of each national innovation system and identifies the fundamental differences among them.

For Russia, the study showed that the overall analysis of the NIS does not explain the strengths and weaknesses of this system. Both the educational and infrastructural dimensions play a prominent role in the economic and social development process within Russian innovation system. While both the institutional and innovation dimensions have no significant impact on the development. This illustrates the need and importance of structural analysis of the NIS's structure in identifying and addressing structural imbalances within the system.

The results of this study are considered a good tool for policymakers to guide innovation policies and strategies to address weaknesses and strengthen strengths to achieve a competitive advantage at the global level. Avoiding weaknesses in national innovation systems in the BRICS countries will help them achieve greater homogeneity and future synergy in innovation, technological and knowledge-based activities that are the shortest and most efficient way to the success of transition process to wardsa knowledge-based economy.

\section{References}

1. Alavi M., \& Leidner D.E. (2001). Knowledge management and knowledge management systems: Conceptual foundations and research issues. MIS quarterly, 107-136.

2. Aleknavičiūtè R., Skvarciany V., \& Survilaitè S. (2016). The Role of Human Capital for National Innovation Capability in Eu Countries. Economics and Culture, 13(1), 114-125. 
3. Alnafrah I. (2016). Towards New Paradigm Development Based on Knowledge Economy in Russia. In Международная научно-техническая конференция молодых ученых БГТУ им. ВГ Шухова (pp. 3984-3988).

4. Alnafrah I., \& Mouselli S. (2017). The Knowledge Society Vis-à-vis the Knowledge Economy and Their Potential Development Impacts in Russia. Journal of the Knowledge Economy, 1-16.

5. Bush, V. (2012). Science-The Endless Frontier (Washington, DC: United States Government Printing Office, 1945). http://www.nsf.gov/od/lpa/nsf50/vbush1945.htm\#transmittal

6. Castellacci F., \& Natera J.M. (2011). A new panel dataset for cross-country analyses of national systems, growth and development (CANA). Innovation and Development, 1(2), 205-206.

7. Castellacci, F., \& Natera, J.M. (2013). The dynamics of national innovation systems: A panel cointegration analysis of the coevolution between innovative capability and absorptive capacity. Research Policy, 42(3). doi:10.1016/j. respol.2012.10.006

8. Den Hertog, P., \& Bilderbeek, R. (2000). The new knowledge infrastructure: the role of technology-based knowledgeintensive business services in national innovation systems. Services and the knowledge-based economy, 222-246.

9. Fagerberg, J., \&Srholec, M. (2008). National innovation systems, capabilities and economic development. Research policy, 37(9), 1417-1435.

10. Freeman, C. (1982), The Economics of Industrial Innovation, second edition, Cambridge (Mass.): MIT Press.

11. Hu, J.L., Yang, C.H., \& Chen, C.P. (2014). R\&D efficiency and the national innovation system: An international comparison using the distance function approach. Bulletin of Economic Research, 66(1), 55-71.

12. Kalanje, C.M. (2006). Role of intellectual property in innovation and new product development. World Intellectual Property Organization.

13. Lundvall, B.A. (2007). National innovation systems-analytical concept and development tool. Industry and innovation, $14(1), 95-119$.

14. Lundvall, $B$ - $A$. (ed.) (1992), National Systems of Innovation: Towards a Theory of Innovation and Interactive Learning, London: Pinter Publishers.

15. Lyasnikov, N.V., Dudin, M.N., Sekerin, V.D., Veselovsky, M.Y., \& Aleksakhina, V.G. (2014). The national innovation system: the conditions of its making and factors in its development. Life Science Journal. Vol. 11, № 6. P. 535-538.

16. Reiljan, J., \& Paltser, I. (2016). Shaping a holistic national innovation system. Riigitervikliku innovatsioonis üsteemikujundamine. Estonian Discussions on Economic Policy, 24(1).

17. Schrempf, B., Kaplan, D., \& Schroeder, D. (2013). National, Regional, and Sectoral Systems of Innovation-An overview. Report for FP7 Project «Progress». European Commission.

18. Tödtling, F., \& Grillitsch, M. (2014). Types of innovation, competencies of firms, and external knowledge sourcingfindings from selected sectors and regions of Europe. Journal of the Knowledge Economy, 5(2), 330-356.

19. Van Lancker, J., Mondelaers, K., Wauters, E., \& Van Huylenbroeck, G. (2016). The Organizational Innovation System: A systemic framework for radical innovation at the organizational level. Technovation, 52, 40-50.

20. Weresa, M.A. (Ed.). (2013). Innovation, Human Capital and Trade Competitiveness: How Are They Connected and Why Do They Matter? Springer Science \& Business Media.

21. Ziemnowicz, C. (2013). Joseph A. Schumpeter and Innovation. Encyclopedia of Creativity, Invention, Innovation and Entrepreneurship, 1171-1176. 